P09-10 TS-1が著効し長期生存が得られた再発 肺癌の 1 例

\section{秋田大学医学部外科学講座呼吸器外科分野}

今井一博, 南谷佳弘, 齊藤元, 中川拓, 細野由希子, 小川純一

症例は55歳，女性．肺腺癌にて左上葉切除術施行．中分化型腺 癌, pT2N2M0, pStageIIIA の診断であった。術後 CDDP+ETP を1コース施行し UFT 内服にて経過観察を行っ た。術後9ヶ月目よりリンパ節再発を認め放射線照射を施行. その後多発肺転移が出現し CDDP+NVB を3コース施行し CR となった．以後, 肺転移の再発, 化学療法, 転移縮小を繰り返 し， CBDCA+NVBを計9コース施行．また右肺部分切除術を 施行した。 その後 gefitinib 内服としたが再度増大. 術後8年経 過した現在，TS-1を内服し CR を維持している．本症例のよう に長期に術後化学療法を行わなければならない場合, 経口抗癌 剤であるTS-1による治療は外来治療が可能であり危篤な副作 用は少なく，また QOL を損なわずに継続できる点で意義があ ると考えられた。
$\mathrm{P} 10-01$

大腸癌肺転移に対する定位放射線治療の 検討

北里大学医学部呼吸器外科学

原英則，小川史洋，松井啓夫，天野英樹，久朗津尚美， 吉村博邦, 佐藤之俊

【目的】近年，早期非小細胞肺癌に対寸る定位放射線治療（SRT）は，手術に 劣らない治療成積を示しているが，転移性肺䭪瘍に関する報告は少ない．また， 大腸癌肺転移では，外科的切除による良好な治療成績の報告もある，そこで， 当院で施行した大腸癌肺転移に対寸るSRT 症例を検討した.【対象】手術不能 ないし手術拒否のためSRTが行われた孤立性の大腸癌肺転移5例を対象とし た。男性2例，女性3例，平均年齢65歳（57７6歳），病巣部位は右上葉3例，右 下葉1例, 左下葉1例, 全て単発性で, 腫瘍長径は $1.3 \sim 2.9 \mathrm{~cm}$ (平均 $1.7 \mathrm{~cm})$ で あった，大腸癌肺転移の診断は，病理診断によるもの 2 例，臨床経過によるも の3例（1例は治療後に病理診断あり）であった.【方法】転移巣に限局して, 動体追跡あるいは呼吸同期を用いた定位照射を施行した。総線量は，48Gy (12Gy $\times 4$ 回)：2例，36Gy（18Gy $\times 2$ 回）：3例であった．治療効果判定には CTを用い，画像変化を経時的に観察し，陰影が増大しないか，治療後の変化 で矛盾しないものを制御，明らかに堌大するものを再発とした（結果I SRT 後，全例に病巣陰影の増大がみられ，再発と判断した，治療より再発までの期 間は，7 25力月（中央値12力月）であった，再発後，2例に外科的切除，2例 にラジオ波狫灼療法が行われ，1例は経過観察中である．現在，外科治療後の2 例は，局所再発及び遠隔転移無し、【結論】大腸癌肺転移は，早期非小細胞肺 癌に対するSRT と比べ，現在の照射方法では制御が難しく，可能な限り外科 治療が望ましい，肺腫瘍に対するSRTの適応に関しては，腫瘍の生物学的特 徵にも配慮し検討寸ることが必要と考えられる（北里大学放射線科学 早川和 重先生との共同研究)

\title{
P10-03 大腸癌の肺転移切除例に関する検討
}

\section{後の関連}

\section{東京大学医学部呼吸器外科}

中島淳, 村川知弘, 深見武史, 吉田幸弘, 長山和弘, 佐野厚, 日下部将史, 杉浦未紀, 北野健太郎, 桑野秀規, 高本眞一

【はじめに】転移性肺腫瘍術後肺転移再発は最大の問題であり，初回肺手術に おける微小転移の術中触診による同定法の意義の問題，胸胿鏡手術の是非，お よび再発後再手術の適応について論議されてきた，単一施設，結腸直腸癌肺転 移を対象とした後ろ向き解析を行った。

【対象と方法】：対象は1996年～2005年, 当科結晹直腸癌肺転移切除連続117症 例. 初回術後平均観察期間は $35.8 \pm 27.5$ 个月.

【結果】肺手術数1回73例，2回32例，3回10例，4回2例，計175回の手術を施行， 術死2例（肺血栓塞栓症1，胃潰湟出血1）。胸胿鏡手術は初回手術72例 $(63 \%)$ ， 2回目29例 $(66 \%) ， 3$ 回目7例 $(58 \%) ， 4$ 回目1例（50\%）で行われ，初回と2回 目以後で胸䏕鏡手術の頻度に有意差無し.ただし術後同側肺再発 $(\mathrm{N}=31)$ に 対しては胸䏕鏡13回 $(42 \%)$ ，それ以外 $(\mathrm{N}=144)$ では96回（67\%）であり有 意差が見られた $(\mathrm{p}=0.01)$. 初回術後肺内外に再発は87例, 2回目術後再発31例, 3回目8例であり，肺再切除の適応となった割合は各々 $51 \% ， 39 \% ， 25 \%$ で，低 下傾向にあった（ $\mathrm{p}=0.24$ 有意差なし）。肺転移初回術後 2 年・ 3 年・ 5 年生存率は 1回手術例 $71.9 \% ， 54.9 \% ， 43.1 \%$ ，2回手術例 $93.5 \% ， 71.9 \% ， 41.5 \% ， 3 \sim 4$ 回手術 例 $91.7 \% ， 81.5 \%, 81.5 \%$ ，有意差あり ( $\mathrm{p}=0.037$ ，Wilcoxon）。

[考察】：結腸直腸癌肺転移術後再発に対方る再切除に扔いて胸腔鏡は初回手術 と同程度行われたが，同側肺転移に対しては開胸術が多く行われた，再切除症 例は行われなかった症例と比べ予後良好であった，原因としては再手術可能な 程度の再発を示す腫瘍の生物学的特性ならびに再手術の治療効果の両者の可能 性が考えられた。

\section{九州がんセンター呼吸器科部}

小副川敦, 福山誠一, 田川哲三, 平井文彦, 綿屋洋, 山崎宏司, 瀬戸貴司，一瀬幸人

【目的】進行大腸癌に対する化学療法の進歩により，15-20ヶ月の 生存期間中央值（MST）が得られるようになった，一方で，大腸 癌肺転移切除後の5年生存率は21-62\%であり, 切除可能な場合は 手術が推められている。当院における大腸癌肺転移切除症例の予 後解析を行った。【方法】1986年 .2006年の間に大腸癌肺転移の切 除が行われた 90 例について検討した.【結果】年齢は平均64歳，男 性46例，女性44例であった，肺転移までの観察期間中央值は 23 ケ 月で, 肺切除後の観察期間中央值は20ヶ月であった。初回肺転移 個数は1-10個，肺切除回数は1-5回であった，全症例における MST は35ヶ月であった. Log-rank 検定による単変量解析では, $\mathrm{CEA}<5 \mathrm{ng} / \mathrm{ml}$ の) 症例 (MST 未到 達) は $\geqq 5 \mathrm{ng} / \mathrm{ml}$ の症例 $(\mathrm{MST}=28$ ケ月）より予後良好であり $(\mathrm{p}=0.01)$, 初回肺転移が 1 個 である症例（MST=69ヶ月）は，2個以上の症例（MST=26ヶ月） より予後良好であった $(\mathrm{p}=0.01)$. 性別, 術式, 肺転移までの観察 期間, 原発巣の病期や部位, 分化度による差は認められなかった。 Cox の比例ハザードモデルによる多変量解析では， CEA < $5 \mathrm{ng} /$ $\mathrm{ml}$ がハザード比 0.36 (0.17-0.81), $\mathrm{p}=0.01$, 初回肺転移 1 個が 0.50 (0.23-1.13), $p=0.09$ という結果であった.【考察】大腸癌肺転移に ついて，特に $\mathrm{CEA}<5 \mathrm{ng} / \mathrm{ml}$, 孤発例において良好な予後が得ら れた。一方で CEA 高值, 多発例では化学療法単独と同程度の予 後であり，今後，手術適応についての検討が必要と考えられる． 